УАK 347.243

ББК 67.407 .1

DOI 10.22394/1682-2358-2021-6-74-83

E.V. Zazolina, assistant lecturer at the Constitutional and Civil Law Department, Dubna State University, Head of the Territorial Department No. 27 of the Branch of Rosreestr Department in Moscow Region

\section{LEGAL REGULATTION \\ OF THE "GARAGE \\ AMNESTY” IN RUSSIA: PROBLEMATIC \\ ASPECTS \\ OF IMPLEMENTATION \\ AND POSSIBLE WAYS \\ OF IMPROVEMENT}

Legal basis for the representation of land plots for the placement of garages is considered. The state of modern Russian legislation in relation to "garage" land and property relations is analyzed. Proposals to improve the current legislation in the field of accounting and registration procedures regarding real estate - garages, are made.

Key words and word-combinations: land plot, Land Code of the Russian Federation, garage, ownership, Rosreestr.
E.B. Зазолина, ассистент кафедрог конститучионного, гражданского права Государственного университета "Аубна», начальник территориального отдела № 27 Филиала Управления Pосреестра по Московской области (email: elena_ zazolina@mail.ru)

ПРАВОВОЕ РЕГУАИРОВАНИЕ ПРОВЕАЕНИЯ «ГАРАЖНОЙ АМНИСТИИ» В РОССИИ: ПРОБАЕМНЫЕ АСПЕКТЫ РЕААИЗАЦИИ И ВОЗМОЖНЫЕ ПУТИ СОВЕРШЕНСТВОВАНИЯ

Аннотация. Рассмотрены правовые основы предоставления земельных участков для размещения гаражей. Проведен анализ состояния современного российского законодательства в отношении «гаражных» земельно-имущественных отношений и внесены предложения по совершенствованию текущего законодательства в сфере осуществления учетно-регистрационных процедур в отношении объектов недвижимости - гаражей.

Ключевые слова и словосочетания: земельный участок, Земельный кодекс РФ, гараж, право собственности, Росреестр.

И

заавна на Руси проблемы земельных отношений, возникновения прав на землю, аграрного вопроса явцялись «исходной точкой» в соџиально-экономическом развитии и становцении государства. В современной России зе-

74 Bulletin of the Volga Region Institute of Administration • 2021. Vol. 21. № 6 
мельное законодательство динамично развивается с учетом как потребностей общества, так и соџиально-экономической обстановки.

Начиная с 1990 г., в связи с введением института частной собственности и возможности приватизации объектов недвижимости в обществе возрос интерес к оформлению права собственности на неАвижимое имущество - в частности на земельные участки, занятые постройками хозяйственного, бытового назначения, в том числе на земельные участки, занятые гаражами (как отдельно стоящими, так и в составе ГСК). Процедура оформления прав, существовавшая на тот период, предполагала многочисленные обращения гражАан в местные органы власти, земельные городские (районные) комитеты, органы БТИ и была весьма затруднительной и затянутой по времени. В большинстве случаев попытки оформить право собственности на объекты недвижимости (приобретенные гражданами в 1960-1980-х годах) заканчивацись отрицательным результатом в сицу того, что отсутствоваци необходимые правоустанавцивающие Аокументы.

Аия упрощения и мегализации процедуры оформления прав граждан на принадлежащие им объекты недвижимости в России был принят Федеральный закон от 30 июня 2006 г. № 93-Ф3 «О внесении изменений в некоторые законодательные акты Российской Федерации по вопросу оформления в упрощенном порядке прав граждан на отдельные объекты недвижимого имущества» - так называемая «дачная амнистия» [1]. Аанным нормативно-правовым актом была введена упрощенная процедура оформления прав граждан на землю для дачного хозяйства, огородничества, садоводства, индивидуаАьной-жилищного строительства, а также на объекты индивидуального жилой застройки, расположенные на земельных участках под указанные цели.

Исходя из положительного опыта реализации «дачной амнистии», законодатель в целях наполнения реестра объектов недвижимости достоверными сведениями, исключения существующих противоречий в записях ЕРГН о земельных участках, правильности кадастрового учета и определения принадлежности земельных участков к определенной категории земель и исключения случаев «наложения и пересечения» земельных участков физических киџ с землями месного фонда принимает Федеральный закон от 29 июмя 2017 г. № 280-Ф3 «О внесении изменений в отдельные законодательные акты Российской Федерации в џелях устранения противоречий в сведениях государственных реестров и установления принадлежности земельного участка к определенной категории земель [2], который в Аальнейшем получает название «месная амнистия». 
Несмотря на достаточно масштабную законодательную работу, проАеланную в сфере мегализации вещных прав и учета объектов недвижимости, Ао последнего времени оставался незатронутым в правовом регулировании вопрос о правовом статусе гаражкей и о возможнности оформиения земли под объектами гаражного строительства.

Необходимость установмения правового режима «гаражкной недвижимости» приобрела особую актуальность в последние годы, хотя ранее подобного рода законопроекты разрабатывацись. Законопроект от 12 апреля 2016 г. № 1043216-6 «О праве собственности на гаражи и гаражных объединениях» [3] не был принят. В 2019 г. законопроект № 785806-7 «О праве собственности на гаражи и гаражных объединениях» находияся на рассмотрении в Совете Государственной Аумы, но при проведении процеАуры общественных слушаний конкретного результата не получил [4].

С 1 сентября 2021 г. в России начал действовать Федеральный закон от 5 апреля 2021 г. № 79-Ф3 «О внесении изменений в отдельные законодательные акты Российской Федерации» [5] (Аалее - Закон № 79-Ф3), получивший неофициальное название «гаражнная амнистия». Проект Закона № 79-ФЗ разрабатывался на протяжении Авух мет Министерством экономического развития РФ с участием Федеральной службы государственной регистрации, кадастра и картографии (Росреестр). В процессе создания законопроекта проводилась также работа с органами исполнительной власти как в регионах, так и с органами местной власти на местах. Принятию закона о гаражной амнистии способствовало совпадение таких факторов, как соџиальный аспект и общественный запрос.

Термин «амнистия» больше относится к уголовному законодательству и в переводе с греческого означает "заб̈вение", "прощение" [6, с. 50]. По всей видимости, Закон № 79-ФЗ получиц в народе название «гаражная амнистия» по аналогии с проводимыми в России «дачной» и «лесной» амнистиями. Указанный нормативно-правовой акт не несет в себе функции полного или частичного освобождения от наказания или замены наказания на более мягкое. По сути Закон № 79-ФЗ ориентирован на граждан, в свое время построивших и фактически владевших гаражами, не имея на построенные объекты каких-либо правоустанавцивающих документов. Это объясняется тем, что на период начала фактического владения и / или строительства гаражей отсутствова$\Lambda$ а нормативно-правовая база дмя мегализации права собственности на объекты гаражного строительства.

Вступивший в силу Закон № 79-ФЗ призван разрешить накопившиеся проблемы при оформлении гаражной собственности. Отметим, что до 
момента принятия указанного Закона в России «гаражный вопрос» был не охвачен в правовом пиане и тем самым в сущности находицся вне правового поля государства. Анализируя основные положения Закона № 79-ФЗ, было бы правильнее говорить о «земельно-гаражной амнистии», так как механизм Закона № 79-Ф3 направлен в большей части на оформление прав на земельные участки, на которых располагаются объекты гаражного назначения. Указанный нормативно-правовой акт вносит изменения в достаточно большое количество федеральных законов, в том числе в Земельный кодекс РФ [7] и в Федеральный закон от 25 октября 2001 г. № 137-Ф3 «О введении в действие Земельного кодекса Российской Федерации» [8] , по вопросам, регулирующим порядок предоставления земельных участков под объектами гаражной неАвижимости. Следует отметить, что законодатель «дал на откуп» органам исполнительной власти субъектов РФ установление перечня документов, необходимых гражданину дмя подтверждения своих прав на земемьный участок под гаражом в случае отсутствия у мица необходимых документов, установленных ч. 5-7 ст. 3.7 Закона № 137-ФЗ. Этот шаг законодателя обусловлен прежкде всего тем, что с 1990-х годов в разных субъектах правовое регулирование регистрации прав на недвижимое имущество осуществлялось разрозненно - указами Президента РФ, актами субъектов РФ, которые, в свою очередь, самостоятельно опредемяли порядок осуществления и проведения процеАуры государственной регистрации прав.

Законом № 79-ФЗ определено, что подлежкат амнистии объекты, введенные в действие до вступления в силу Градостроительного кодекса РФ от 29 декабря 2004 г. [9]. Опредемяя временные рамки Аля объектов, попадающих под амнистию, законодатель опирался на эмементы действующего гражданского законодательства и законодательства в градостроительной деятельности. На институт приобретательной давности (ст. 234 Гражданского кодекса РФ [10]), согласно которому миџо, добросовестно, открыто владеющее объектами недвижимости в течение пятнадцати мет, приобретает право собственности на это имущество. Законодатель учел и тот факт, что Градостроительным кодексом РФ были введены первые нормы регулирования градостроительной деятельности на федеральном уровне. Ао этого правовое регулирование градостроительной деятельности в регионах осушествлялось в отсутствие единого нормативного акта федерального уровня. Таким образом, Градостроительный кодекс РФ закрепил необходимость получения разрешительной документации на землю как обязательного условия Аля осушествления строительных работ и возведения объектов недвижимости, в противном случае объект недвижимости расценивается как самовольная постройка. 
Отметим, что законодатель предоставиц возможность применения норм «гаражной амнистии» гражданам, «использующим» гараж (ч. 2 ст. 3.7 Закона № 137-Ф3), но при этом в Законе не содержится норм, разъясняющих это понятие, а такжке норм о необходимости представмения подтверждающих документов об использовании гаражка непосреАственно по его исходному назначению - хранению автотранспортных средств. Следовательно, остается неясным вопрос о возможности применения правиц «гаражной амнистии» Амя миц, кто имеет гаражи, но, к примеру, не имеет транспортного средства или использует гаражные объекты с целью извлечения прибыли - как мини-автосервисы, или использует гаражи для хранения продовольственных и непроАовольственных товаров. Указанное несоответствие можно расценить как упущение законодателя и нуждается в уточнении существующей нормы данного Закона, изможив его ч. 2 ст. 3.7 следующим образом: «...использующим гараж Аля хранения автотранспортных средств и сезонного хранения автошин».

Законом № 79-ФЗ введены новая терминология и понятия, касающиеся объектов гаражной недвижимости. Понятие «гаражный боко» заменено на термин «гараж». В Законе прямо указывается, что гаражные боксы, которые могут быть блокированы общими стенами с Аругими гаражами, иметь общие коммуникации, крышу, стены, то есть располагаться в одном гаражном блоке (пенале), признаются и считаются отАельно стоящими объектами недвижимости и Аолжны учитываться в реестре объектов недвижимости как здание. Попытаемся разобраться в терминологии таких объектов недвижимости, как «гаражный бокс» и «гараж».

В российском законодательстве по настояшее время отсутствуют мегальные определения понятий «гаражный боко и «гараж». Имеется закрепление трактовки понятия «гараж» в СП 113.13330.2016 «Стоянка автомобимей. Актуацизированная редакщия СНиП 21-02-99» [11]: «ЗАание и сооружение, помешение Аля стоянки (хранения) ремонта и технического обскуживания автомобилей, мотоциклов и Аругих транспортных средств; может быть как частью жилого дома (встроенно-пристроенные гаражи), так и отдельным строением». Закон о «гаражной амнистии», вводя новую терминологию при определении гаражных боксов, которые в своей сущности явцяются нежилыми помешениями, признает их самостоятельными объектами недвижимости - зданиями. Аля цемей закрепления новой терминологии законодателю следовало вкАючить в Закон № 79-ФЗ норму, поясняющую офиџиальное понятие «гараж». Введение в российское законодательство мегального понятия «гараж» позволит наиболее эффективно осуществлять правовое регули- 
рование отношений, связанных как с возведением, эксплуатацией объектов гаражного строительства, так и с вопросами оформления прав на земельные участки под гаражами.

Законодатель в ст. 18 Закона № 79-ФЗ делает отсылку к Федеральному закону от 13 июмя 2015 г. № 218-Ф3 «О государственной регистрации неАвижимости» (Аалее - Закон № 218-Ф3) [12] и отмечает, что с 1 сентября 2021 г. гаражные боксы и гаражи следует учитывать в ЕАином государственном реестре недвижимости (Аалее - ЕГРН) с видом объекта неАвижимости как здание, при этом указать назначение - «гараж». По объектам гаражной недвижимости, которые уже внесены в сведения ЕГРН и на которые уже в записях в ЕГРН внесены сведения о зарегистрированных правах (в том числе выданы на руки собственникам правоудостоверяющие документы - свидетельства о государственной регистрации права или выписки из ЕГРН), законодатель указывает на необходимость внесения соответствующих изменений в уже имеющиеся записи ЕГРН о виде объекта и его назначении. При этом законодатель установиц заявительный принцип внесения такого рода изменений, определив круг миц, имеющих право на обращение в орган регистрации права: непосреАственно собственник гаража; гражАанин, которому предоставлен земельный участок под гаражом; миџо, уполномоченное решением общего собрания гаражно-строительного кооператива или органы исполнительной власти / местного самоуправления. Аействующим Законом № 218-ФЗ предусмотрена проџеАура учета изменений в сведениях ЕГРН в связи с приведением вида объекта недвижимости в соответствие с требованиями действующего законодательства. Сегодня на практике при рассмотрении такой учетно-регистрационной процедуры государственный регистратор прав (работник Росреестра) сталкивается с технической стороной вопроса. Информационная система ФГИС ЕГРН, с применением которой осуществАяется внесение записей в ЕГРН, технически не позвоцяет провести процедуру изменения вида объекта недвижимости.

Устанавливая заявительный принџип внесения изменений в сведения ЕГРН о гаражной неАвижимости (о виде объекта и о его назначении), законодателем не было учтено, что не все внесенные до 1 сентября 2021 г. в ЕГРН сведения о гаражах будут приведены в соответствие с требованиями действующего Закона № 79-ФЗ. Обусловлено это прежде всего тем, что зависит от волеизъявления гражАан - собственников гаражей. Таким образом, с целью наполнения ЕГРН достоверными и соответствующим действуюшему законодательству сведениями, а также с целью минимизации обращений граждан в органы регистрации прав и повышения качества оказываемых услуг в сфере кадастрового 
учета и регистрации прав на недвижимое имущество преАстав яется возможным рекомендовать Росреестру инициировать проведение процедуры по автоматическому изменению в записях ЕГРН сведений о виде объекта (изменить с вида «помешение» на «здание») и указать назначение объекта - гараж.

Законодатель предлагает также искмючить из состава сведений ЕГРН записи о зданиях, сооружениях, в которых были расположены гаражипомещения в связи с изменением у гаражей-помещений вида объекта на здание (п. 1 ч. 2 ст. 18 Закона № 79-ФЗ). Указанное возможно цишь в том случае, когда в записях ЕГРН у всех учтенных в гаражном блоке (пенале) гаражах-помещениях будут учтены в ЕГРН изменения в отношении вида этих объектов, то есть Аанная норма (п. 1 ч. 2 ст. 18 Закона № 79-Ф3) возможна к реализации в случае массового и одновременного внесения в записи ЕГРН изменений о виде объектов недвижимости гаражей-помешений.

Согласно положениям Закона № 79-ФЗ в круг Аиџ, в отношении которых действует «гаражная амнистия», входят граждане - физические цица, при этом согласно ч. 15 ст. 3.7 Закона № 137-ФЗ установлено, что земельный участок под гаражом может быть преАоставлен в собственность наследнику гражданина, который владел гаражом, явцяющимся объектом капитального строительства и возведенным Ао Аня введения в действие Градостроительного кодекса РФ от 29 декабря 2004 г. Рассматриваемая норма «о наслеАнике гражАанина» Аолжна быть скорректирована законодателем в части указания «наследнику гражданина из числа физических миц». В противном случае, исходя из толкования указанной нормы и учитывая положения п.1-2 ст. 1116 ГК РФ, закон о «гаражной амнистии» будет действовать в том числе и в отношении владельцев гаражей - юридических миџ и органов государственной власти Российской Федерации.

Правила приятого Закона № 79-ФЗ распространяют свое действие и на предоставление земельных участков, подмежкащих образованию из состава земельного участка, который ранее был выдемен гаражному кооперативу или иной организации Аля размещения гаражей (ст. 2 Закона № 137-Ф3). Важно отметить, что в России подавмяющее большинство собственников гаражей явцяются чценами гаражных кооперативов, а земельные участки изначально предоставлялись всему гаражному кооперативу в постоянное бессрочное пользование или на праве аренды. В связи с этим преАставцяется необходимым предусмотреть правовой механизм дмя реализации процедуры формирования земельного участка под гаражом гражданина из состава уже ранее сформированного и предоставленного земемьного участка гаражному коопера- 
тиву. Законодатель указывает в ч. 17 ст. 3.7 Закона № 137-ФЗ, что при выдемении и образовании земельного участка под гараж, подмежащий предоставлению гражданину, из состава земельного участка, который изначально был предоставлен гаражному кооперативу на определенном виде права, согласие кооператива на образование земельного участка не требуется. При этом законодатель определиц, что исходный земельный участок (ранее предоставленный в пользование или в аренду гаражному кооперативу мибо иной организации) остается в измененных границах, а право гаражного кооператива на образуемый земельный участок прекрашается.

Предложенный законодателем механизм формирования земельных участков под гаражами не в полной мере соответствует нормам действующего Земельного кодекса РФ в части установленного порядка образования земельных участков.

Ссылаясь на сведения ЕГРН [13], в России на большую часть земельных участков, ранее предоставленных гаражным кооперативам, сегодня оформлено право аренды, а земельные участки внесены в свеАения ЕГРН как ранее учтенные объекты неАвижимости.

Согласно установленному механизму, условие о получении согласия от гаражного кооператива на образование земельного участка Амя эксплуатации гаража не требуется. Указанное правицо идет «в разрез» с требованиями ч. 4 ст. 11.2 Земельного кодекса РФ, которой закрепляется, что «образование земельных участков допускается при наличии в письменной форме согласия землепользователей, землевладельцев, арендаторов, залогодержкателей исходных земельных участков». Условие об искцючении необходимости получения согласия от гаражного кооператива на образование формируемого участка может быть проАиктовано стремлением законодателя оптимизировать и упростить для граждан процесс оформления «гаражной недвижимости». Но возникает следующий вопрос о правах так называемых третьих киџ на исходный участок - гаражных кооперативов. У них имеются оформленные отношения с органами местного самоуправления на пользование исходным земельным участком. При этом необходимо учитывать, что при оформлении права на земельный участок, подлежащий предоставмению гражданину под его гараж, исходный земемьный участок будет оставаться в измененных границах. Следовательно, одновременно с проџедурой постановки на учет формируемого земельного участка в сведения ЕГРН одновременно вносятся изменения в исходный земельный участок в части указания площади объекта. В силу ч. 3 и 4 ст. 8 Закона № 218-ФЗ сведения о площади земельного участка явмяются оАной из основных характеристик объекта, что позволяет выделить такой 
объект недвижимости в качестве индивидуально-определенной вещи. Таким образом, дия упорядочивания земельных отношений гаражным кооперативам придется обрашаться в органы местного самоуправления с целью внесения изменений в договоры аренды и заключения дополнительных соглашений к договорам. Учитывая большое количество объектов «гаражной недвижимости», гаражным объединениям и кооперативам придется не один раз обращаться в районные / городские комитеты по управлению имуществом за внесением соответствующих изменений в документы на землю. На этом уровне представляется возможным рекомендовать законодателю разработать и внеАрить правовой рычаг Амя оптимизирования процедуры по учету изменений в Аокументы на землю у гаражных кооперативов, так как в противном случае их постоянное обращение в местные администрации приведет к значительному увеличению числа Аокументов, что, в свою очереАь, может добавить приличный объем работы дмя органов исполнительной власти / органов местного самоуправлеиия и затруднить сам процесс работы этих органов.

Так называемый закон о гаражной амнистии (Закон № 79-Ф3) только начал действовать. Механизм реализации гаражной амнистии до конца не отработан, еше предстоит решение многих проблемных задач и вопросов дмя мегализации гаражной недвижимости. Тем не менее первый шаг со стороны законодателя сделан - на законодательном уровне принят закон об упрошенном оформлении прав на объекты гаражной недвижимости и земельные участки поА ними. Принятие закона о гаражной амнистии имеет своей цемью урегулировать существующие вопросы приобретения и оформления гражАанами своих прав на гаражки и земельные участки, занятые гаражами. Поставленные в Аанной публикации вопросы и возможные пути их реализации в основном относятся к проблеме преобразования системы государственного кадастрового учета и регистрации права собственности на гаражи, что в настоящее время является одним из приоритетных направлений в сфере правового регулирования оборота объектов недвижимости в отечественном законодательстве.

\section{Библиографический список}

1. О внесении изменений в некоторые законодательные акты Российской Федерации по вопросу оформления в упрощенном порядке прав граждан на отдельные объекты недвижимого имущества: Федер. закон от 30 июня 1996 г. № 93-ФЗ (в ред. от 30 апр. 2021 г.) // С3 РФ. 2006. № 27. Ст. 2881.

2. О внесении изменений в отдельные законодательные акты Российской Федерации в целях устранения противоречий в сведениях государственных реестров и установления принадлежности земельного участка к определенной категории земель: 
Федер. закон от 29 июля 2017 г. № 280-ФЗ (в ред. от 30 апр. 2021 г.) // СЗ РФ. 2017. № 31 (ч. І). Ст. 4829.

3. О праве собственности на гаражи и гаражных объединениях: проект Федер. закона № 1043216-6 (в ред., внесенной в Государственную Думу РФ, текст по состоянию на 12 апр. 2016 г.). URL: http://asozd.duma.gov.ru/

4. О праве собственности на гаражи и гаражных объединениях: проект Федер. закона № 785806-7 (в ред., внесенной в Государственную Думу РФ, текст по состоянию на 30 авг. 2019 г.). URL: http://sozd.parlament.gov.ru/

5. О внесении изменений в отдельные законодательные акты Российской Федерации: Федер. закон от 5 апр. 2021 г. № 79-ФЗ // С3 РФ. 2021. № 15 (ч. І). Ст. 2446.

6. Большой советский энциклопедический словарь / под ред. А.М. Прохорова. М., 1986.

7. Земельный кодекс Российской Федерации от 25 окт. 2001 г. № 136-Ф3 (в ред. от 2 июля 2021 г.) // СЗ РФ. 2001. № 44. Ст. 4147.

8. О введении в действие Земельного кодекса Российской Федерации от 25 окт. 2001 г. № 137-ФЗ (в ред. от 5 апр. 2021 г.) // СЗ РФ. 2001. № 44. Ст. 4148.

9. Градостроительный кодекс Российской Федерации от 29 дек. 2004 г. № 190-Ф3 (в ред. от 2 июля 2021 г.) // СЗ РФ. 2005. № 1 (ч. 1). Ст. 16.

10. Гражданский кодекс Российской Федерации (часть первая) от 30 нояб. 1994 г. № 51-Ф3 (в ред. от 28 июня 2021 г.) // СЗ РФ. 1994. № 32. Ст. 3301.

11. СП 113.13330.2016 «Стоянка автомобилей. Актуализированная редакция СНиП 21-02-99» СНиП 21-02-99: приказ Министерства строительства и жилищно-коммунального хозяйства РФ от 7 нояб. 2016 г. № 776/пр (в ред. от 10 дек. 2017 г.) // Информационный бюллетень о нормативной, методической и типовой проектной документации. 2017. № 3.

12. О государственной регистрации недвижимости: Федер. закон от 13 июля 2015 г. № 218-ФЗ (в ред. от 2 июля 2021 г.) // СЗ РФ. 2015. № 29 (ч. І). Ст. 4344.

13. ФГИС ЕГРН // Официальный сайт. URL: http://egrnn.ru/fgis/ 